\title{
最近の中国繊維工業の概況
}

本報告は 50 年代から 90 年代までの 40 年間の中国の 繊維工業についての資料の分析である. しかし前の 30 年間 (50年代 80 年代) の資料は保存状態が悪く, 完全ではない，そして，その30年間の概況を分析す るのは背景的に複雑である。なぜならば，この30年 間，中国で政治的な動乱があり，経済的な面であ不 安定であった。 しかし，この30年間で, 繊維工業は 緩慢ながらも変化し，生産増加の傾向はみられた。

ここで，入手した資料から，最近10年間の中国の 繊維工業の情勢をま之めて分析を試みる.

\section{1. 中国紡織業の発展の情勢}

紡織業の総生産額をみると，1980年は682億元（日 本円で1.45兆円位) で, 全国工業総生産額 $(4,992$ 億 元）の13.7\%を占めていた. 1990年紡織業の総生産

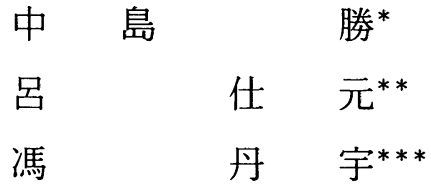

額は 1,668 億元で，全国工業総生産額（1 兆3,747億 元）の $12.1 \%$ 占めていた. 10年間で、紡織業の総 生産額が全国工業総生産額に占める割合は1.6\%下 がっているが，その総生産額の絶対值は前より 3 倍 近くになり，急速な発展の情勢が見られる。 また， 各繊維の生産の設備の推移から見ればこの 10 年間に 大幅の増加が見られる（表 5).

\section{2. 化学繊維の発展, 天然繊維の増産}

この10年間で，化学繊維製品は著しく発展した。 1990年の生産額は（254億元）1980年（54億元）の約 5 倍になっている。 アパレル産業も大きな発展を続 け，1990年は1980年の 3 倍になった（表 1)。これは 開放経済下のこの 10 年間に消費の割合が大きくなっ たからである（表 7). また，化学繊維の1991年の生

表 1 GNP, GNIおよびGNP, GIN/人（億元）

\begin{tabular}{l|c|c|r|r|r}
\hline \hline 年 & 1962 & 1970 & 1980 & 1990 & 1991 \\
\hline 人口（億） & 6.7295 & 8.2992 & 9.8705 & 11.4333 & \\
\hline GNP & & & 4470.0 & 17400.0 & \\
\hline GNP/人 (元/人) & & & 456.0 & 1533.0 & \\
\hline GNI & 924.0 & 1926.0 & 3688.0 & 14300.0 & \\
\hline GNI/人 (元/人) & 139.0 & 235.0 & 376.0 & 1260.0 & \\
\hline
\end{tabular}

中国織維産業の生産額

\begin{tabular}{l|r|r|r|r|r}
\hline \multicolumn{1}{c|}{ 年 } & \multicolumn{1}{c|}{1962} & \multicolumn{1}{c|}{1970} & \multicolumn{1}{c|}{1980} & \multicolumn{1}{c|}{1990} & 1991 \\
\hline 全国工業総生産額 & 343.0 & 2421.0 & 4992.0 & 13747.0 & \\
\hline テキスタイル（紡緎） & 94.0 & 316.0 & 682.0 & 1668.0 & 2175.8 \\
\hline 同上比率 & 27.4 & 13.1 & 13.7 & 12.1 & \\
\hline 化学繊維 & 1.0 & 8.0 & 54.0 & 254.0 & \\
\hline アパレル（衣料） & 32.0 & & 135.0 & 390.0 & \\
\hline
\end{tabular}

「中国統計年鑑1991」より

M. Nakajima*, Lu Shiyuan**, Feng Danyu***, A General Situation of Nowaday in Chinese Textile Industry, *京都工芸緎維 大学繊維学部, Kyoto University of Technology, $* *$ 無錫軽工学院, Wuxi Institute of Light Industry, $* * *$ 京都工芸緎維大学 留学生, Hangzhon Zhejiang Institute of Silk Textile Technology 
表 2 紡織工業の税金と利潤総額 [億元]

\begin{tabular}{|c|c|c|c|c|}
\hline 年 & 1975 & 1980 & 1985 & 1990 \\
\hline 税金の総額 & 80.0 & 157.4 & 139.4 & 95.9 \\
\hline 化学繊維 & 2.0 & 9.7 & 8.9 & 21.4 \\
\hline 綿加工織物 & 53.8 & 106.2 & 71.4 & 45.7 \\
\hline 綿ニット & 7.0 & 15.1 & 13. 0 & 1.9 \\
\hline 羊毛 & 6.9 & 11.9 & 21.8 & 5.0 \\
\hline 麻 & 1.3 & 2.9 & 4.0 & -2.4 \\
\hline 絹 & 3.6 & 6.6 & 11.9 & 14.8 \\
\hline 紡織機械 & & 3.8 & 5.8 & 7.8 \\
\hline \multicolumn{5}{|l|}{ I } \\
\hline 年 & 1975 & 1980 & 1985 & 1990 \\
\hline 工賃総額（億／年） & & & 1 & 119.5768 \\
\hline 平均工賃 (元 $/$ 年 $\cdot$ 人) & & & & 2212 \\
\hline
\end{tabular}

中国紡織工業出版社「中国紡織年鑑」1991.より

表 4 天然繊維

\begin{tabular}{c|r|r|r|r|r|r}
\hline 年 & 1952 & \multicolumn{1}{|c|}{1957} & \multicolumn{1}{c|}{1965} & 1978 & 1989 & 1990 \\
\hline 綿 & 130.35 & 164.00 & 209.35 & 216.70 & 378.80 & 450.77 \\
\hline リネン & 30.55 & 30.05 & 27.90 & 108.8 & 66.02 & 72.61 \\
\hline ラミー & 4.05 & 5.25 & 2.95 & 2.60 & 15.45 & 8.91 \\
\hline 蔐 & 6.20 & 6.80 & 6.65 & 17.75 & 43.38 & 48.02 \\
\hline 羊毛 & 3.36 & 4.30 & 7.49 & 13.82 & 23.73 & 18.89 \\
\hline ヤギ & 0.13 & 0.04 & 0.80 & 0.76 & 1.62 & 1.10 \\
\hline カシミヤ & 0.21 & 0.23 & 0.41 & 0.30 & 0.54 & 0.50 \\
\hline
\end{tabular}

産実績は表 3 を参照されたい.

天然繊維の綿, 羊毛, 絹, 麻などは気候などに左 右されやすく変動が激しい, 一部の天然繊維の生産 高があまり増えない原因としては, 化学繊維の生産 コストが低下したこと, 徐々に化学繊維に代替され てきたことなどによる.しかし，同じ天然繊維でも 綿や絹の生産は年々発展の傾向がみられる (表 4). 特に絹は価格が最近の10年間毎年上昇してきたので 生産を促してきた. 加えて, 重要なことは絹が中国 の民族産業であり, 文化の発展の重要なシンボルで あるということである.「シルクの国」という名声を 保持することが中国の各時代の責務であある.
表 3 化学繊維の生産量

\begin{tabular}{|c|c|c|c|c|c|}
\hline \multicolumn{3}{|c|}{ 地 区 } & 1970 & 1980 & 1990 \\
\hline 全 & 国 総 & 計 & 100,913 & 450,331 & $1,648,172$ \\
\hline 北 & 京 & 市 & 22,893 & 25,947 & 39,844 \\
\hline 上 & 海 & 市 & 20,085 & 151,548 & 251,108 \\
\hline 遼 & 寧 & 省 & 12,775 & 59,461 & 155,920 \\
\hline 河 & 南 & 省 & 8,978 & 13,199 & 63,663 \\
\hline 河 & 北 & 省 & 6,845 & $9,901$. & 25,911 \\
\hline 江 & 蘇 & 省 & 5,172 & 32,603 & 407,635 \\
\hline 吉 & 林 & 省 & 5,105 & 11,750 & 30,295 \\
\hline 浙 & 江 & 省 & 3,577 & 13,139 & 85,318 \\
\hline 広 & 東 & 省 & 2,477 & 5390 & 115,775 \\
\hline 甘 & 萧 & 省 & 4,944 & 11,817 & 13,420 \\
\hline 黒 & 龍 江 & 省 & 1,665 & 17,989 & 96,396 \\
\hline 山 & 東 & 省 & 1,493 & 6,821 & 40,771 \\
\hline 天 & 津 & 市 & 1,202 & 8,205 & 74,643 \\
\hline 福 & 建 & 省 & 1,020 & 13,506 & 31,306 \\
\hline 四 & $川$ & 省 & 803 & 15,197 & 38,389 \\
\hline 雲 & 南 & 省 & 501 & 1,008 & 5,114 \\
\hline 湖 & 北 & 省 & 128 & 8,477 & 24,835 \\
\hline 広 & 西 & 省 & 117 & 993 & 13,717 \\
\hline 山 & 西 & 省 & 81 & 3,642 & 19,838 \\
\hline 内 & 蒙 & 古 & 50 & 1,526 & 7,406 \\
\hline 安 & 徽 & 省 & & 5,514 & 12,329 \\
\hline 潮 & 南 & 省 & & 14,685 & 35,118 \\
\hline 海 & 南 & 省 & & & 15,231 \\
\hline \multicolumn{3}{|c|}{ 寧夏回族自治区 } & & & 3,355 \\
\hline 新彊 & イグル自 & 治区 & & & 2,762 \\
\hline 貴 & 州 & 省 & & 3,124 & 3,078 \\
\hline 陕 & 西 & 省 & & 1,559 & 14,996 \\
\hline 江 & 西 & 省 & 1,001 & 13,332 & 19,999 \\
\hline
\end{tabular}

文津出版社「中国繊維手冊」1991. より

\section{3. 紡織関係の郷鎮企業の発展}

80年代中国の農業経済の改革は「郷鎮企業」とい う新しい企業の誕生と発展を促した。 なかでも紡織 関係の郷鎮企業は著しく発展した. 特に長江三角州 としての上海経済区の範囲（上海に近くの江蘇省, 
表 5 瀻維生産の設備

\begin{tabular}{|c|c|c|c|c|c|c|c|}
\hline & UNIT & 1952 & 1957 & 1965 & 1978 & 1989 & 1990 \\
\hline 綿 紡 績 & 万．錘 & 561.00 & 755.60 & 980.10 & $1,561.92$ & $3,565.59$ & $3,881.95$ \\
\hline 綿 織 機 & 万 台 & & 42.14 & 30.92 & 49.65 & 83. 82 & 86.04 \\
\hline 毛 紡 績 & 万 錘 & 12.31 & 15.62 & 27.98 & 47.81 & 252.27 & 265.87 \\
\hline 毛 織 機 & 千 台 & 1.909 & 1.830 & 4. 040 & 7.120 & 32.602 & 33.556 \\
\hline 袋 織 機 & 台 & 1,042 & 1,418 & 1,821 & 5,725 & 15,914 & 16,139 \\
\hline 麻 紡 績 & 万 錘 & 4.80 & 5.40 & 7.65 & 15.00 & 84.89 & 88.98 \\
\hline 繰 系 機 & 万 緒 & 16. 72 & 20.56 & 26.52 & 72.23 & 182.03 & 200.00 \\
\hline 絹 織 機 & 万 台 & 4.42 & 3.09 & 2.67 & 4. 54 & 17.48 & 17.96 \\
\hline 化合緎生産 & 万トン & & 0.03 & 6.70 & 38.10 & 188.27 & 202.45 \\
\hline 化 & 万トン & & 0.03 & 5. 10 & 13. 38 & 21.04 & 21.73 \\
\hline 合 & 万トン & & & 1.60 & 24.72 & 167.23 & 180.72 \\
\hline 綿染色加工 & 億 $\mathrm{m}^{2}$ & & & & 68.66 & 124.11 & 129.40 \\
\hline
\end{tabular}

中国国家統計局「紡織工業主要専業設備」p.309.より

浙江省など）で大きな発展を遂げた。これにはいく つかの原因がある. 第 1 に, この辺は昔ながらに紡 織の産地として有名であり, 紡織技術は長い歴史を 持っている. 第 2 は上海に近く, 世界的なファッシ ョン情報の入手が早く, 流行の潮流を常に維持でき たからである．この上海経済区の郷鎮企業の発展に 従って全国的にあ波及した. 表 3，6 から分かるよう に, 郷鎮企業の経済は農村の経済に大きな発展を促 した，特に農業国の中国において，農村経済の発展 は, 国力の強化, 社会の安定に重要な役割を果たし てきた. 中国の最近 10 年の経済改革の上で郷鎮企業 あひとつの重要な改革である.これはいわゆる「市 場経済路線」の拡大を進めるため重要な試みである と考えられる.

\section{4. 繊維の輸出}

1990年の繊維輸出額は194.90億ドルで，1980年の 49.53億ドルの 4 倍と急速な伸びを示している. 緎 維製品の中で特に衣類の輸出は大きな発展を遂げ た.これは中国が徐々に付加価值を高めた繊維製品 に重点を移してきたからである.

\section{5. 今後の繊維工業の方向}

今後の中国繊維工業の発展方向は国際的な競争や 国内の経済情勢と国民の需要動向によって定まるで あろう。
(1)綿紡績，毛紡績，化学繊維紡績の生産能力の減 少

a. 1992年から1995年にかけて，毎年100万鍾ずつ 隇少する.

表 6 郷鎮企業の紡織品生産の概況

\begin{tabular}{|c|c|c|c|c|c|}
\hline & 年 & .1986 & 1987 & 1989 & 1990 \\
\hline \multirow{2}{*}{ 企 } & 総計 & 25,767 & 30,044 & 31,287 & 29,608 \\
\hline & 綿紡織 & 6,867 & 8,488 & 10,223 & 10,485 \\
\hline \multirow[t]{2}{*}{ 業 } & 毛紡織 & 2,380 & 2,615 & 3,428 & 3,115 \\
\hline & メリヤス & 7,333 & 8,317 & 8,242 & 7,397 \\
\hline 数 & 化学繊維 & 4.98 & 563 & 596 & 547 \\
\hline \multirow{2}{*}{$\begin{array}{l}\text { 従 } \\
\text { 業 }\end{array}$} & 総計 & 254.23 & 290.15 & 309.98 & 309.97 \\
\hline & 綿紡織 & 78.94 & 95.25 & 122.9 & 127.35 \\
\hline \multirow{3}{*}{$\begin{array}{c}\text { 員 } \\
\text { 数 } \\
\text { (万人) }\end{array}$} & 毛紡織 & 44.47 & 61.91 & 103.98 & 101.2 \\
\hline & メリヤス & 60.27 & 63. 35 & 62.39 & 58.88 \\
\hline & 化学繊維 & 4.04 & 4. 75 & 5.07 & 5.57 \\
\hline \multirow{2}{*}{ 生 } & 総計 & 259.57 & 355.79 & 539.84 & 631.49 \\
\hline & 綿紡織 & 84.96 & 116.78 & 207.86 & 253.26 \\
\hline 産 & 毛紡織 & 44.78 & 61.91 & 103.98 & 101.2 \\
\hline \multirow{2}{*}{$\begin{array}{c}\text { 額 } \\
\text { （億人） }\end{array}$} & メリヤス & 39.82 & 52.75 & 88.12 & 91.54 \\
\hline & 化学織維 & 6.21 & 9. 84 & 15.39 & 21.29 \\
\hline
\end{tabular}


表 7 社会消費構成の概況

$(\%)$

\begin{tabular}{|c|c|c|c|c|c|c|}
\hline 年 & 1955 & 1960 & 1970 & 1980 & 1985 & 1990 \\
\hline 食 & 55.6 & 48.2 & 53.4 & 51.2 & 52.7 & 55.4 \\
\hline 服 & 19.8 & 21.7 & 23. 4 & 23. 0 & 18. 9 & 16. 3 \\
\hline 日 用 品 & 13. 9 & 15. 1 & 10.5 & 12. 9 & 13. 9 & 13.7 \\
\hline 文 教 品 & 2.7 & 3.6 & 2.5 & 4.1 & 7.7 & 6.1 \\
\hline 書籍, 雑誌 & 1.0 & 1. 1 & 0.4 & 1.3 & 1.2 & 1.5 \\
\hline 品 & 3.1 & 6.1 & 5.0 & 3. 7 & 2.8 & 4.0 \\
\hline 燃 & 3.0 & 4.2 & 4.8 & 3.8 & 2.8 & 3.0 \\
\hline
\end{tabular}

b. 1991年から1995年までの 5 年間に, 老朽設備 1,000万錘を更新する.

\section{(2)市場経済による生産方針}

輸出品はさらに品質を上げて加工する. 現在, 綿 製品のうち10\%がコーマー通しであるが，1995年は これを15〜20\%にする．また，織布の仕上加工は $50 \%$ に，二次製品化率現在の $50 \%$ から $70 \%$ に引上 げ，市場経済の方針によって全国の大，中，小型の 繊維企業の管理や運営体制や機能を強化する.

(3)全方位で繊維産業を重視

綿以外の繊維, 例えば麻繊維やカシミヤの増産, 差別化繊維や機能繊維などの開発を進める．また， アパレル産業を重視するととあにインテリア分野に あ積極的に参入する。 そして, 産業用テキスタイル の生産比率を $15 \%$ に高める.

(4)緎維生産の現代化を目指し

国際化，情報化，システム化を推進するため，八 イテク技術を利用して, 老朽化した繊維産業や生産 設備を改造, 更新する. 大幅にコンピュータの導入 を進め, 繊維教育, 技術の研究をもっと重視する. そして, 生産の重点は繊維製品の高付加価値化に向 かっている.

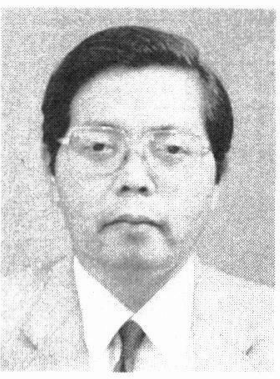

中島勝（なかじままさる） 昭和 51 年京都工芸繊維大学奉 職, 現在までの主研究として自 動織機の経済的最適化コンピュ ータアルゴリズムを設計・作 成, 繊維機械の歯車切削用ホブ の最適在庫計画システムの構 築, 縫製工程のラインバランス の自動編成の考案，アパレルの CIM 化方策の手順作成, 繊維・
表 8 中国繊維の輸出 (百万ドル)

\begin{tabular}{|c|c|c|c|c|c|c|}
\hline \multirow{2}{*}{ 年 } & \multirow{2}{*}{$\begin{array}{c}\text { 輸出 } \\
\text { 総額 (A) }\end{array}$} & \multicolumn{4}{|c|}{ 繊維品の輸出 } & \multirow{2}{*}{$\mathrm{B} / \mathrm{A}$} \\
\hline & & 原料 & 紡織品 & 衣類 & 総額 (B) & \\
\hline 1960 & 1,856 & & & 249 & 656 & 35.3 \\
\hline 1965 & 2,218 & 75 & 295 & 190 & 560 & 25.3 \\
\hline 1970 & 2,260 & 100 & 340 & 155 & 596 & 26.4 \\
\hline 1975 & 7,264 & 245 & 1,033 & 353 & 1,631 & 22.5 \\
\hline 1980 & 18,272 & 544 & 2,756 & 1,653 & 4,953 & 27. 1 \\
\hline 1985 & 27,360 & 1,145 & 3,243 & 2,050 & 6,438 & 23.5 \\
\hline 1990 & 62,068 & 1,094 & 6,998 & 6,848 & 19,490 & 24.3 \\
\hline 1991 & & 578 & 7,734 & 8,998 & & \\
\hline
\end{tabular}

文津出版社「中国瀻維手冊」1991.より

高分子を利用した機器・設備の 設計・試作・評価, テキスタイ ルデザインの工学的価値など. これらは繊維機械学会論文集, 日本機械学会論文集, アメリカ 機械学会論文集などに発表し た.（京都工芸繊維大学繊維学 部， 个606 京都市左京区松ヶ崎 御所海道町, TEL. 075-7247842, FAX. 075-724-7710)

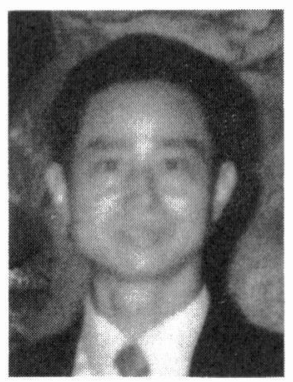

呂 仕 元 (Lu Shiyuan) 中国紡織大学卒, 南通紡織大学 などを経て，現在無錫軽工学院 の紡織分院長.

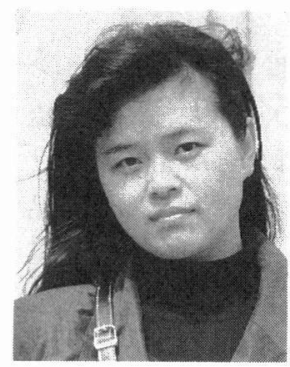

馮 丹 宇 (Feng Danyu) 昭和59年中国杭州浙江絲綢工学 院卒, 約 6 年間シルク織物のデ ザインを経験, 平成 3 年 9 月か ら京都工芸緎維大学留学, テキ スタイルデザインを専攻. 